\title{
EFFECT OF SPECIALTY STORE ENVIRONMENT ON CONSUMERS' EMOTIONAL STATES: THE MODERATING ROLE OF PRICE CONSCIOUSNESS
}

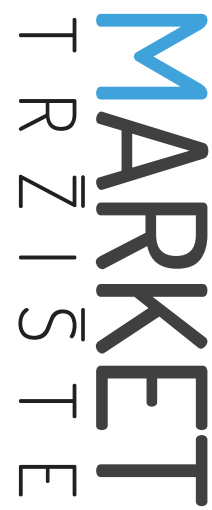

\section{UČINAK OKRUŽENJA SPECIJALIZIRANE PRODAVAONICE NA POTROŠAČEVO EMOCIONALNO STANJE: MODERATORSKA ULOGA CJENOVNE OSJETLJIVOSTI}

\section{Mateja Kos Koklič}

University of Ljubljana, Faculty of Economics, Kardeljeva ploščad 17, 1000 Ljubljana, SLOVENIA, e-mail: mateja.kos@ef.uni-lj.si

\begin{abstract}
Purpose - This research study seeks to explore the effect of retail environment on consumer behavior outcomes, mediated by consumers' emotional states in the stimulus-organism-response framework. It is suggested that the atmosphere, as represented by ambient and social factors, and employees positively influence the customer purchase experience, and this experience positively influences the intention to become a return customer. Additionally, the moderating effect of price consciousness is proposed. While customer experience is defined as a multi-dimensional construct, the focus of this study is the affective dimension due to its relevance in defining the importance of experience.
\end{abstract}

Design/Methodology/Approach - Computer-assisted personal interviewing was used to gather data from 298 visitors of specialized garden centers in Slovenia. The hypotheses were tested using structural equation modeling.

Findings and implications - The results indicate that both the atmosphere and employees positively influence customer experience (pleasure and arousal). More

\section{Sažetak}

Svrha - Istraživanjem se nastoji ispitati učinak maloprodajnog okruženja na ishode ponašanja potrošača posredovane potrošačevim emocionalnim stanjem temeljenim na poretku poticaj-organizam-reakcija. Pretpostavlja se da atmosfera, koju predstavljaju ambijent i društveni faktor, te zaposlenici pozitivno utječu na potrošačev doživljaj kupovine, koji pozitivno utječe na namjeru povratka potrošača. Nadalje, predlaže se moderatorski učinak cjenovne osjetljivosti. lako se potrošačev doživljaj definira kao višedimenzionalni konstrukt, ovo je istraživanje usmjereno na afektivnu dimenziju zbog njezine relevantnosti u definiranju važnosti doživljaja.

Metodološki pristup - Računalno potpomognuto osobno intervjuiranje korišteno je za prikupljanje podataka od 298 posjetitelja specijaliziranih vrtnih centara u Sloveniji. Hipoteze su testirane primjenom modeliranja strukturnih jednadžbi.

Rezultati i implikacije - Rezultati pokazuju da i atmosfera i zaposlenici pozitivno utječu na doživljaj potrošača (na zadovoljstvo i uzbuđenje). Konkretnije, ambijent i zaposlenici povećavaju zadovoljstvo, ambijent i društveni 
specifically, ambience and employees increase pleasure, while ambience and the social factor increase arousal. Pleasure also increases an individual's desire to become a return customer, while arousal decreases the intention. The results further reveal a significant moderating effect of price consciousness on three relationships: ambience-pleasure, ambience-arousal, and social factor-pleasure.

Limitations - The data used to test the conceptual model were cross-sectional, but a longitudinal approach could provide more insight into the relationships. In addition, more specific elements of the environment could be integrated into the model to better explain the customer purchase experience.

Originality - The study seems to be the first one to explore the moderating role of price consciousness in the relationship between the retail environment and consumers' emotional states.

Keywords - customer purchase experience, customer emotions, atmosphere, employees, intention to revisit, price consciousness faktor povećavaju uzbuđenje. Zadovoljstvo također povećava i individualnu želju za povratkom potrošača, dok uzbuđenje smanjuje tu namjeru. Rezultati nadalje otkrivaju značajan moderatorski učinak cjenovne osjetljivosti na tri odnosa: ambijent-zadovoljstvo, ambijent-uzbuđenje i društveni faktor-zadovoljstvo.

Ograničenja - Podatci korišteni za testiranje konceptualnog modela bili su presjek (jednokratno istraživanje), a longitudinalni bi pristup mogao pružiti više uvida u odnose. Usto, u model bi se mogli integrirati specifičniji elementi okruženja kako bi se bolje objasnio potrošačev doživljaj kupovine.

Doprinos - Čini se da je ovo prvo istraživanje koje istražuje moderatorsku ulogu cjenovne osjetljivosti u odnosu između maloprodajnog okruženja i potrošačeva emocionalnog stanja.

Ključne riječi - potrošačev doživljaj kupovine,potrošačeve emocije, atmosfera, zaposlenici, namjera za ponovnim dolaskom, cjenovna osjetljivost 


\section{INTRODUCTION}

Over the past few decades, scholars and practitioners alike have paid increasing attention to the study of customer experience (e.g., Choudhury, Singh \& Saikia, 2016; Steenkamp \& Maydeu-Olivares, 2015), which has a strong influence on the course and outcome of the purchase process (Zeithaml, Bitner \& Gremler, 2009). Lemon and Verhoef (2016) assert that creating a strong customer experience has become the foremost management objective. Positive experiences influence the company's competitive advantage and customer satisfaction, resulting in an increase in the amount of money and time spent by customers at the business, as well as in a greater likelihood that they may recommend the business to others and become return customers (Bolton, Gustafsson, McColl-Kennedy, Sirianni \& Tse, 2014; Johnson, Kim, Mun \& Lee, 2015; Moreira, Fortes \& Santiago, 2017; Nadiri \& Gunay, 2013).

Therefore, cognizance of the characteristics of customers and their behavior is crucial to providing the highest-quality shopping experience (Berry, Carbone \& Haeckel, 2002). Despite this relevance, customer-experience research remains fragmented and lacks a holistic theoretical foundation of the antecedents and consequences of customer experience (McColl-Kennedy et al., 2015). Also, the academic marketing community has been slow to adopt these developments in the field of customer experience (Verhoef et al., 2009). Notwithstanding concerted efforts to disentangle the customer experience, existing research has largely neglected the issue of how individual consumer characteristics may affect the relationship between customer experience and its antecedents and consequences. Dabholkar and Bagozzi (2002) emphasize that it is much more meaningful to study the moderating effects of external factors, such as consumer traits, than to merely assess direct effects. Hence, this research study aims to address these shortcomings by examining a set of antecedents and consequences of customer-purchase experiences in a retail context and, more importantly, to investigate the moderating effect of price consciousness on these relationships. In addition, the present research also responds to calls by Petermans, Janssens and Van Cleempoel (2013) to investigate customer experiences in in-store environments using an all-inclusive approach.

The study contributes to the existing literature in several ways. First, it investigates the moderating role of price consciousness, defined as the degree to which consumers focus on paying low prices (Lichtenstein, Ridgway \& Netemeyer, 1993). Price consciousness is one of the few consumer traits that have shown their academic and practical relevance across numerous studies. Very few studies on customer experience have investigated consumer characteristics as potential moderators. Several authors have researched the moderating role of consumer goals (e.g., Kaltcheva \& Weitz, 2006), while far less attention has been paid to other types of consumer moderators, such as price sensitivity or price consciousness. Second, previous studies have provided mixed results on the influence of customer experience, especially its affective dimension, on various consequences (e.g., Donovan, Rossiter, Marcoolyn \& Nesdale, 1994; Kaltcheva \& Weitz, 2006). Hence, this study attempts to improve the understanding of the relationship between customer experience and the intention to become a return customer. Third, the validity of the findings will be enhanced by collecting data from a sample of actual buyers immediately after their visit to the selected store. By doing so, some of the limitations of previous studies, for example, the use of a laboratory setting rather than the real environment (e.g., Kaltcheva \& Weitz, 2006) or employing student samples instead of actual buyers (e.g., Nadiri \& Gunay, 2013), will be overcome. An incremental contribution also lies in testing the proposed model in a specialty-store setting. As a result, additional insight into some of the previously investigated relationships and their cross-contextual validation will be offered.

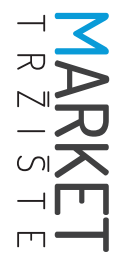


The remainder of the paper is organized as follows: First, a short literature review is provided to shed more light on the customer experience. Next, a conceptual model of customer experience in a retailing context is proposed, and theoretically grounded hypotheses are presented. In the third section, the research methodology is described in more detail, encompassing the sampling procedure, measurement instrument, and sample characteristics. A two-step procedure for analyzing data via structural equation modeling is outlined subsequently. The final section provides a critical discussion of the results and the implications derived from them, delineating some limitations of the study, and suggesting directions for future research.

\section{THEORETICAL BACKGROUND}

The existing literature offers a variety of definitions for customer experience. Verhoef and others (2009) referred to it as a multi-dimensional construct that involves cognitive, affective, emotional, social, and physical responses to the retailer, while Bolton and others (2014) emphasize all the interactions that customers have with a company through all touch points - during search, purchase, consumption, and post-consumption. In a similar vein, Schmitt (2003) explicates the multi-dimensional nature of experience using five types of experiences: sensory, affective, cognitive, physical, and social-identity. On the other hand, Schmitt, Brakus and Zarantonello (2015) depict customer experience as holistic in nature, resulting from the purchase and consumption of products as part of a value exchange between a buyer and a seller.

The customer-experience concept has been studied from various theoretical angles. One of the theories serving as a framework for the study of customer experience is service-dominant logic, which is centered on doing things with the customer versus doing things to the customer. Consequently, it prioritizes understanding customer experience (Lusch, Vargo
\& O'Brien, 2007; Vargo \& Lusch 2004). Another influential framework has been proposed by Pine and Gilmore (1998; 1999) who suggested that, in the experience economy (as the fourth stage in the economic progression), the highest-value economic offerings are experiences. A somewhat different yet holistic approach has been proposed by Schmitt (1999), advocating five dimensions to qualify experiences: think, feel, sense, act, and relate. One theory in particular stands out as a comprehensive theoretical framework that may be useful for disentangling the customer experience as a result of the (service) environment: the Stimulus-Organism-Response (SOR) model (Donovan \& Rossiter, 1982; Mehrabian \& Russell, 1974; Otterbring, 2017; Sherman, Mathur \& Smith, 1997). The main premise of the model is that environmental stimuli affect an individual's emotional state, which in turn influences final actions or responses (Mehrabian \& Russell, 1974). The stimuli are external to the recipient and consist of various elements in the environment. The organism describes internal processes or states, while the response results in approach or avoidance behavior. The SOR paradigm has served as a strong guideline for studies on consumer decision-making for decades. This has also been the case in the retail setting, where this seminal conceptualization has provided the basis for numerous studies on the effects of internal store environment on shopping behavior (Vieira, 2013).

As noted, stimulus (S) is the first dimension in the SOR framework. Several typologies of the environmental stimuli have been introduced in the past few decades. Mehrabian and Russell (1974) suggested using the information rate or loading as the key variable to distinguish between the two stimuli. Later, Baker (1986) devised a three-category typology composed of: ambient factors (non-visual cues), design factors (visual cues), and social factors (people in the store). Similarly, Bitner (1992) also proposed three categories, although slightly different from Baker: ambient cues (those affecting five senses), spatial layout (layout and functionality), and signage (signs, symbols, and artifacts). Inter- 
estingly, Verhoef and others (2009) consider the social environment (including other customers and employees) a separate category from the retail atmosphere (e.g., design, scent, temperature). Overall, it could be stated that among the key causal determinants of customer experience, the physical environment, social environment, service, quality and price of products, promotions, and the employee attitude toward customers are particularly elucidated (Chahal \& Dutta, 2014; Puccinelli et al., 2009; Verhoef et al., 2009). In the retailing context, scholars and practitioners predominantly emphasize two aspects of the environment as crucial for shaping customer experience, namely, the atmosphere and employees (Spies, Hesse \& Loesch, 1997). The atmosphere in the store is believed to have a measurable effect on emotional factors such as pleasure and arousal (Donovan et al., 1994). Various types of atmospheric factors (visual, auditory, olfactory, tactile, and gustatory) have been shown to influence visitors' perceptions and behaviors, with a combined influence being even greater than the sum of its parts (Spence, Puccinelli, Grewal \& Roggeveen, 2014).

In the SOR model, the organism component (O) has been defined as the affective and cognitive intermediary states and processes (Eroglu, Machleit \& Davis, 2001). These two types also correspond to the multifaceted nature of consumer experience, as suggested by various scholars (e.g., Schmitt, 1999; Verhoef et al., 2009). The emotional element of customer experience has been particularly pertinent in retail, where customers encounter products, brands, and employees and where they might, consequently, experience intense emotions (Mattilla \& Enz, 2002). Emotions represent a focal dimension of the customer-purchase experience. High relevance of emotions is further underscored by Dasu and Chase (2013), who argue that emotions actually define the importance of the experience. Likewise, Martin, Mortimer and Andrews (2015) empirically demonstrated that the affective experiential state, unlike the cognitive experiential state, plays a significant role in the shaping of purchase intentions. Accordingly, Mehrabian and Russel (1974) posited that the effect of stimulus in consumer behavior is mediated by the consumer's emotional state, which can be described along three domains: pleasure-displeasure (P), arousalnon-arousal (A), and dominance-submissiveness (D), also known as PAD. Most work in the field of environmental psychology has employed this framework and recognized its usefulness (Eroglu et al., 2001). An important objective of retailers is to develop environments that increase the states of customer pleasure and arousal, and avoid atmospheres that create customer submissiveness (Hoffman \& Turley, 2002).

As already stated, according to Mehrabian and Russell (1974), all responses (R) to an environment can be classified as approach or avoidance behaviors. Approach behaviors encompass positive behaviors that might be directed at a particular place (retail store), for example, a desire to explore a particular environment, a desire to communicate with others and experience satisfaction with the surroundings. Inversely, avoidance behaviors reflect the opposite to these behaviors. Donovan and Rossiter (1982) observed several types of approach behaviors related to the retailing context, for example, the enjoyment of shopping, returning to the store, friendliness toward others (visitors or personnel), time spent browsing and spending money. In fact, the emotional state of a customer as part of his or her purchase experience has an impact on several factors relevant to the company, such as brand equity (Yoon \& Oh, 2016). The existing literature has extensively dealt with customer satisfaction, which is the main outcome of the purchase, in addition to trust (Grewal, Levy \& Kumar, 2009; Meyer \& Schwager, 2007; Verhoef et al., 2009). Both concepts are of utmost importance for retailing. Furthermore, several types of behavioral intentions have been posited as the outcomes of customer experience, including purchase and return-customer intentions (Moreira et al., 2017; Morrison, Gan, Dubelaar \& Oppewal, 2011), and word-of-mouth promotion of the business (Jang \& Namkung, 2009).

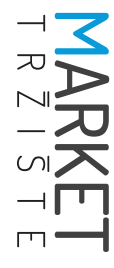


To advance the understanding of the relationships between customer experience and its antecedents and consequences, relatively few authors examined potential moderators that influence these relationships. Verhoef and others (2009) proposed a conceptual framework of customer-experience creation in which they divided moderators into two groups: those tied to the situation and those tied to the consumer. The examples of situational moderators include the type of store, location, and season, whereas consumer moderators encompass goals, task orientation, and consumer attitudes. One of the few empirical studies on moderators in the context of customer experience was conducted by Kaltcheva and Weitz (2006), who investigated the effect of motivational orientation as a consumer moderator.

\section{CONCEPTUAL FRAMEWORK AND RESEARCH HYPOTHESES}

Based on these foundations, a conceptual model grounded in the well-established SOR and PAD frameworks (Mehrabian \& Russell, 1974) is proposed to examine the influence of environment on in-store buying behavior (Figure 1). The model posits that the atmosphere and employ- ees influence customer purchasing experiences. More specifically, the store atmosphere is reflected in two elements that have been demonstrated to be relevant in the retailing context (Baker, 1986): the ambient factor (or ambience) and the social factor. In our case, ambience refers to the non-visual elements of a store's environment: music, scents, and temperature. The social factor captures the perceptions of other visitors in the store (Baker, Grewal \& Parasuraman, 1994), and the employee construct refers to the perception of employee attitudes toward customers.

In the model, customers' emotions serve as an indicator of customer experience; hence, two of the PAD dimensions are pleasure and arousal. The dominance dimension is left out due to its poor predictive power, demonstrated in similar research contexts (e.g., Donovan et al., 1994). Pleasure refers to the degree to which an individual feels good, joyful, happy, or satisfied in a situation, while arousal reflects the degree to which an individual feels excited, stimulated, alert, or active in the situation (Donovan \& Rossiter, 1982). Furthermore, customer experience is hypothesized to positively influence the intention to revisit. Responding to the calls of Verhoef and others (2009) for more research on moderating effects of situational and consumer

FIGURE 1: Conceptual model of customer purchase experience

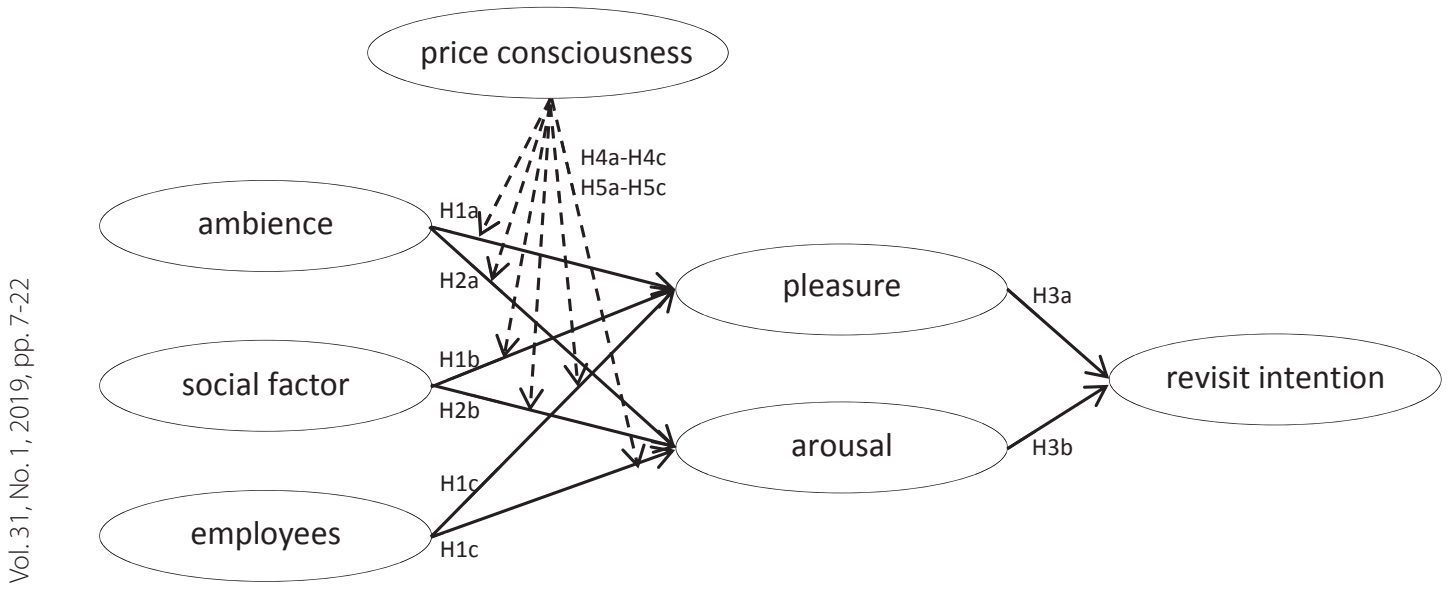


moderators in customer experience research, it is also proposed that an individual's consciousness regarding price will moderate the relationships between customer experience and its antecedents. As already mentioned, price consciousness represents a consumer trait of high relevance in times of change when consumers become more price conscious. Price consciousness might lead to reduced loyalty while intensifying consumer willingness to switch from their favored brands. Hence, it has been recognized as a fundamental marketing construct, relevant to various marketing audiences but especialy to marketing strategy experts (Hampson \& McGoldrick, 2017; Koschate-Fischer, Hoyer, Stokburger-Sauer \& Engling, 2017).

The first set of hypotheses addresses the relationships between atmosphere (ambience and the social factor) and employees, with pleasure and arousal as two dimensions of customer emotions (or customer experience). Several authors have demonstrated that the customer's emotional response is based on the store environment (e.g., Donovan et al., 1994). For example, a meta-study by Vieira (2013) indicated that there is a significant positive impact of environment on pleasure, as well as on arousal. Sherman and others (1997) hypothesized that ambience and social factors positively influence pleasure and arousal. They provided empirical support for the positive influence of social factors on pleasure and of ambience on arousal. Interestingly, they could not substantiate the impact of social factors on arousal or the impact of ambience on pleasure. Although in a slightly different research context, Ryu and Jang (2007) also found a positive influence of ambience on both pleasure and arousal, while Moreira and others (2017) demonstrated that sensory stimuli that are part of the environment positively influence brand experience.

In this particular study, the social factor refers to how visitors are perceived by respondents. Another social aspect relevant to the shaping of customer emotions is the perception of employees. Both visitors/shoppers and employees are considered part of the social environment that Verhoef and others (2009) conceptualize as an antecedent of customer experience. Several studies have looked into the relationship between employee behavior and customer experiences. Berry and others (2002) suggest that employees provide different cues to customers based on which customer experience is formed. Ryu and Jang (2007) empirically demonstrated that employees represent social cues that positively influence customers' affective responses. Given that the customer experience consists of pleasure and arousal, employees are expected to have an impact on both dimensions. Based on the argumentation, the following hypotheses are proposed:

Hypothesis 1: Ambience (1a), the social factor (1b), and employees (1c) positively influence pleasure.

Hypothesis 2: Ambience (2a), the social factor (2b), and employees (2c) positively influence arousal.

In the second set of hypotheses, the relationships among pleasure, arousal, and the intention to become a return customer are examined. Based on a meta-analytic review, Vieira (2013) concluded that both pleasure and arousal positively impact patronage behavior and behavioral intention. Hart, Farrell, Stachow, Reed and Cadogan (2007) demonstrated that an enjoyable shopping experience has a significant positive influence on customers' intentions to become return customers. Contrary to their expectations, Moreira and others (2017) found no significant effect on purchase intentions stemming from brand experience. Similarly, Spies and others (1997) concluded that pleasure has no effect on purchase intentions, while Milliman (1982) identified a negative relationship between arousal and intention. To address these inconsistencies, the following hypotheses are posited:

Hypothesis 3: Pleasure (3a) and arousal (3b) positively influence the revisit intention.

Finally, the fourth set of hypotheses refers to the moderating effect of price consciousness on 
the relationships between customer experience and its antecedents. Verhoef and others (2009) maintain that consumer characteristics moderate the relationship between retail atmosphere, social environment, and customer experience. Following their argument, this study focuses on price consciousness as the degree to which a customer is unwilling to pay a higher price for a product (Lichtenstein, Bloch \& Black, 1988). Consumers who are more price-conscious tend to derive emotional value and entertainment from shopping for lower prices, and they are more cognitively involved with price (Alford \& Biswas, 2002). Ailawadi, Neslin and Gedenk (2001) suggested that a pleasing physical design lowers economic costs, while Baker and others (1994) concluded that positive ambience and social dimension of the store environment increase perceived price acceptability. Given that price consciousness corresponds to price acceptability, it is suggested that consumers who are more price-conscious will derive a more positive experience from the environment, compared with consumers who are less price-conscious:

Hypothesis 4: Price consciousness positively moderates the relationship between ambience and pleasure (4a), the social factor and pleasure (4b), and employees and pleasure (4c).

Hypothesis 5: Price consciousness positively moderates the relationship between ambience and arousal (5a), the social factor and arousal (5b), and employees and arousal (5c).

\section{METHODOLOGY}

To test the conceptual model, computer-assisted personal interviewing was used to gather data from visitors of four specialized garden centers in Slovenia. In the final sample of 298 respondents, individuals who were visiting the store at the time the research was conducted were invited to participate. The interviewers asked the visitors to answer a 10-minute questionnaire. All participants were awarded coupons for a discount to be used in any of the brand's garden centers.
The final sample consisted of $71.5 \%$ females and $28.5 \%$ males, with an average age of 55 years (standard deviation 14.6). The biggest age group was made up of respondents between 55 and 64 years of age (33.9\%), followed by the group of 65 -year-olds and up (28.2\%). A similar profile in terms of gender and age has been employed in previous studies among the visitors of garden centers (e.g., Hudson, Behe, Ponder \& Barrick, 1997). In terms of education, well over a half of the sample said they had completed secondary education (64.5\%), $25.5 \%$ had tertiary education, and $12 \%$ had completed only primary education. More than a half of the sample consisted of retired individuals (56.8\%), while $30.8 \%$ were still employed. The demographic characteristics of the sample are also presented in Table 1.

TABLE 1: Demographic characteristics of the sample

\begin{tabular}{|c|c|c|c|}
\hline Variable & $\begin{array}{c}\% / M \\
\text { (SD) }\end{array}$ & Variable & $\%$ \\
\hline \multicolumn{2}{|l|}{ Gender } & \multicolumn{2}{|l|}{ Education } \\
\hline Women & 71.5 & Primary level & 12.0 \\
\hline Men & 28.5 & $\begin{array}{l}\text { Upper } \\
\text { secondary level }\end{array}$ & 64.5 \\
\hline Age (years) & $\begin{array}{c}55 \\
(14.6)\end{array}$ & Tertiary level & 25.5 \\
\hline Up to 24 & 3.7 & \multicolumn{2}{|c|}{ Occupational status } \\
\hline 25 to 34 & 10.7 & Employed & 30.8 \\
\hline 35 to 44 & 7.4 & Unemployed & 6.2 \\
\hline 45 to 54 & 16.1 & Retired & 56.8 \\
\hline 55 to 64 & 33.9 & Student & 4.8 \\
\hline $65+$ & 28.2 & Other & 1.4 \\
\hline
\end{tabular}

The construct measures were based on the existing literature, but were adapted to the specific research context and pretested on a sample of 35 buyers in one of the garden centers. Ambience, the social factor, employees, and revisit intention were measured on a seven-point Likert scale, in which 1 indicated 'completely disagree' and 7 indicated 'completely agree'. Both am- 
bience and social factor were measured using a three-item scale, each based on a study by Sherman and others (1997). The perception of employees was captured by means three items borrowed from a study Cronin and Taylor's (1992). Customer-experience items were adapted from the research of Mehrabian and Russel (1974) and Sherman and others (1997) and consisted of four pleasure items and four arousal items, all measured on an eight-point semantic differential scale. Revisit intention was measured using one item ('I will definitely return to the garden center Kalia.'). Price consciousness was assessed using the scale originally developed by Wells and Tigert (1971) and widely employed in the retail context (e.g., Alford \& Biswas, 2002; Zielke \& Komor, 2015). The measurement items are listed in the Appendix.

\section{DATA ANALYSES AND FINDINGS}

The conceptual model was tested using structural equation modeling, conducted in two steps (Anderson \& Gerbing, 1988). First, the measurement model was evaluated to establish uni-dimensionality, reliability, and validity of the constructs. The final measurement model was modified, taking into consideration the theoretical limitations, validity of indicators, and modification diagnostics. Accordingly, statistically insignificant items and items measuring more than one construct were excluded from the model. Based on the model-fit indices, the estimated measurement model provided a good fit for the data. Specifically, the RMSEA (0.039) and sRMR (0.040) were below 0.8, while CFI (0.97) and GFI (0.93) were above the required value of 0.90 (Kline, 2011), with a chi-square value of 226.962 and 157 degrees of freedom.

Subsequently, the structural model was examined using t-statistics to test the relationships among the constructs. In addition, since price consciousness was hypothesized to play a moderating role, factor scores were created for the predictors (ambience, the social factor, and em- ployees) and the moderator (price consciousness) using exploratory factor analysis. Then the products of those factor scores were created and used as single indicators in testing the structural model.

The data conformed well to the model, as was evident in the model-fit measures: chi-square = 317.480, d.f. $=164, \mathrm{CFI}=0.94, \mathrm{GFI}=0.92$, RMSEA $=0.054, \mathrm{sRMR}=0.066$. All multi-item constructs displayed adequate average variance extracted (AVE) and composite reliability (CR), the former ranging from 0.506 to 0.646 and the latter from 0.748 to 0.877 . All values were above the cut-off of 0.50 and 0.70 for AVE and CR, respectively (Fornell \& Larcker, 1981; Nunnally \& Bernstein, 1994). To test for discriminant validity, values of the correlation coefficients among the latent variables were examined, and were not found to be very high. Additionally, the AVE of each construct was compared with the shared variance between the constructs (Farrell, 2010). The latter was significantly lower, thereby confirming discriminant validity.

The results suggest that pleasure is significantly positively influenced by ambience and employees (standard regression coefficient $(\mathrm{SRC})=$ 0.68 and 0.16 ), thereby supporting $\mathrm{H} 1 \mathrm{a}$ and $1 \mathrm{C}$, but not by the social factor (SRC $=-0.02$ ), so H1b was not supported. On the other hand, ambience and the social factor significantly positively influence arousal (SRC $=0.50$ and 0.15) (providing support for $\mathrm{H} 2 \mathrm{a}$ and $\mathrm{H} 2 \mathrm{~b}$ ), while employees seem to have no significant impact on arousal (SRC $=0.05)$, hence $\mathrm{H} 2 \mathrm{C}$ was not supported. Explained variance for pleasure and arousal amounted to $54.5 \%$ and $36.8 \%$, respectively. As hypothesized, pleasure was found to have a significant positive impact on the intention to revisit (SRC $=0.41$ ), thus H3a was supported. Contrary to our expectations, arousal decreases an individual's revisit intention (SRC $=-0.14)$, hence $\mathrm{H} 3 \mathrm{~b}$ was not supported. The explained variance for intention was $13.8 \%$. In the case of testing the moderating effect, empirical support was provided for three out of the six hypotheses. Price consciousness was found to significantly

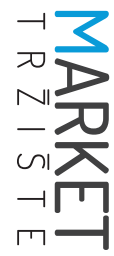


moderate the relationships between ambience and pleasure (SRC $=0.19 ; \mathrm{H} 4 \mathrm{a}$ supported), the social factor and pleasure $(S R C=0.15$; H4b supported), and ambience and arousal (SRC $=0.29$; H5a supported). Table 2 displays test statistics and results regarding the research hypotheses.

\section{DISCUSSION OF RESULTS}

This study investigates how store environment and employees define emotional states, which, in turn, influence behavioral intentions. Additionally, the moderating effect of price con-

TABLE 2: Conceptual model testing

\begin{tabular}{|l|l|c|c|}
\hline & Structural Path & $\mathbf{( 1 )}$ & (2) \\
\hline $\mathrm{H} 1 \mathrm{a}+$ & ambience $\rightarrow$ pleasure & $0.68\left(7.70^{*}\right)$ & supported \\
\hline $\mathrm{H} 1 \mathrm{~b}+$ & social factor $\rightarrow$ pleasure & $-0.02(-0.27)$ & not supported \\
\hline $\mathrm{H} 1 \mathrm{c}+$ & employees $\rightarrow$ pleasure & $0.16\left(2.39^{*}\right)$ & supported \\
\hline $\mathrm{H} 2 \mathrm{a}+$ & ambience $\rightarrow$ arousal & $0.50\left(5.79^{*}\right)$ & supported \\
\hline $\mathrm{H} 2 \mathrm{~b}+$ & social factor $\rightarrow$ arousal & $0.15\left(2.36^{*}\right)$ & supported \\
\hline $\mathrm{H} 2 \mathrm{c}+$ & employees $\rightarrow$ arousal & $0.04(0.57)$ & not supported \\
\hline $\mathrm{H} 3 \mathrm{a}+$ & pleasure $\rightarrow$ revisit intention & $-0.14\left(-2.07^{*}\right)$ & not supported \\
\hline $\mathrm{H} 3 \mathrm{~b}+$ & arousal $\rightarrow$ revisit intention & $0.19\left(3.46^{*}\right)$ & supported \\
\hline $\mathrm{H} 4 \mathrm{a}+$ & price cons. $\rightarrow$ ambience - pleasure & $0.15\left(2.96^{*}\right)$ & supported \\
\hline $\mathrm{H} 4 \mathrm{~b}+$ & price cons. $\rightarrow$ social factor - pleasure & $-0.08(-1.40)$ & not supported \\
\hline $\mathrm{H} 4 \mathrm{c}+$ & price cons. $\rightarrow$ employees - pleasure & $0.29\left(4.72^{*}\right)$ & supported \\
\hline $\mathrm{H} 5 \mathrm{a}+$ & price cons. $\rightarrow$ ambience - arousal & $0.06(1.11)$ & not supported \\
\hline $\mathrm{H} 5 \mathrm{~b}+$ & price cons. $\rightarrow$ social factor - arousal & $-0.05(-0.83)$ & not supported \\
\hline $\mathrm{H} 5 \mathrm{c}+$ & price cons. $\rightarrow$ employees - arousal & & \\
\hline
\end{tabular}

Notes: (1) Std. regression coefficient (t-value); (2) Result; * one sided p-value $<0.05$

In addition to testing the moderating effect of price consciousness, its direct effect on exogenous variables was also tested. The results indicate that there is no quasi moderation effect of price consciousness. In fact, only the moderating effect of prices consciousness on ambience and pleasure remained significant. Moreover, the indirect effects of the environmental stimuli on the revisit intention were also examined. The analysis revealed that the indirect effect of ambience on revisit intention (SRC $=0.205$ ) was the strongest, followed by employees (SRC = 0.059), and the social factor ( $S R C=-0.027)$. However, the indirect effect of the social factor was insignificant probably due to the fact that, relatively speaking, the effect of the social factor on arousal was comparable in size, but opposite in value to the effect of arousal on revisit intention. sciousness is examined. By gathering and analyzing data from 298 visitors to specialized garden centers, the proposed research hypotheses are tested, and support is provided for the majority. The findings suggest that the likable ambience and positively perceived employees increase customers' pleasure ( $\mathrm{H} 1 \mathrm{a}$ and $\mathrm{H} 1 \mathrm{c})$, while the social factor reflected in positively perceived visitors seems to play no significant role in shaping an individual's feelings of pleasure (H1b). Interestingly, Sherman and others (1997) found no effect of ambience on pleasure, while Morrison and others (2011) provided empirical evidence of a significant positive effect. Regarding the insignificant impact of the social factor on pleasure, our finding is not aligned with the result of Sherman and others (1997). It is possible that the role of the social factor (visitors in our study) 
was a different one, depending on the particular context, e.g., the role of other visitors might be less prominent in the case of garden centers, compared with shopping malls.

In the next set of hypotheses, the roles of two atmosphere factors - ambience and the social factor - and the employees' factor were tested on how they shape the arousal dimension of the consumer experience. Overall, it can be concluded that atmosphere (i.e., ambience and the social factor) positively influences arousal ( $\mathrm{H} 2 \mathrm{a}$ and H2b). Although Sherman and others (1997) hypothesized such relationships, they only found support for the impact of ambience, but not of the social factor. Based on our study, a positive perception of employees does not seem to increase visitors' arousal $(\mathrm{H} 2 \mathrm{C})$, although previous studies demonstrated such a link (e.g., Ryu \& Jang, 2007). Perhaps the role of employees in shaping arousal turned out to be negligible due to their cordial interaction with the respondents during their time at the store.

The third set of hypotheses suggests that both pleasure and arousal increase behavioral intentions. The author found strong empirical support for the positive impact of pleasure on the revisit intention $(\mathrm{H} 3 \mathrm{a})$. Contrary to expectations, arousal decreases the revisit intention ( $\mathrm{H3b}$ ). This finding is consistent with Kaltcheva and Weitz (2006), who found that in situations when consumers are task- (not recreationally) oriented, arousal negatively influences behavioral intentions. Hence, a plausible explanation for the negative effect in our case is that the task-oriented motivation was predominant among respondents.

As a result of examining the relative contribution of the antecedents to emotional states, ambience emerged as the strongest driver of both pleasure and arousal. This corresponds to the outcome of the study by Ryu and Jang (2007), in which ambience was the most influential factor affecting customers' pleasure and arousal. Furthermore, the finding that pleasure is the strongest determinant of the revisit intentions is well aligned with the meta-study by Vieira
(2013), which demonstrated a greater impact of pleasure on shopping behavior across numerous studies.

Finally, this study reveals that price consciousness plays a significant moderating role in the case of several relationships. It has been empirically verified that the more price-conscious consumers are, the stronger the effect of ambience on pleasure $(\mathrm{H} 4 \mathrm{a})$, of the social factor on pleasure ( $\mathrm{H} 4 \mathrm{~b})$, and of ambience on arousal ( $\mathrm{H} 5 \mathrm{a})$. Following on the premise by Baker and others (1994) that price is perceived as more acceptable in a pleasant ambience and in an environment with adequate sales personnel, it is assumed that consumers who are more price conscious will have a stronger experience (pleasure and arousal) from ambience and partly from other visitors.

\section{CONCLUSIONS}

These findings shed more light on how the store environment - physical and social - is reflected in the customer purchase experience and further in their intended behavior. Moreover, the moderating effect of price consciousness as a personal characteristic is examined.

Several implications for retailers might be derived from this study. It is important to consider not only the offering and pricing of various items, but also the atmosphere in the store and the employees' attitude and behavior toward customers. These factors substantially shape customers' emotional responses as part of their purchase experience. More specifically, these responses are manifested in the feelings of pleasure and arousal experienced by customers. Customer experience has been recognized as an emerging marketing concept for practitioners in the current experiential economy.

Aligned with Sherman and others (1997) and Nadiri and Gunay (2013), the study also attests to the importance of paying attention to consumers' emotional states on account of their subsequent behavioral intentions. Specifically,

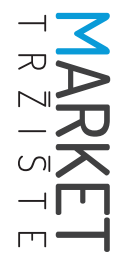




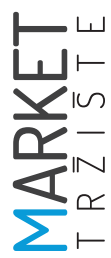

experiencing pleasure leads to a stronger revisit intention, while arousal decreases this intention. In light of the baffling finding regarding the opposite impact of pleasure and arousal on intention, a retailer's insight into motivational orientation might prove helpful (Kaltcheva \& Weitz, 2006).

Enhancing the pleasurable experience elevates indeed the chances that customers will come back to the store. This can be achieved via two routes: through the perception of ambience and through the perception of employees. Based on the analysis of the indirect effects, it might be concluded that ambience exerts the strongest indirect effect on the revisit intention. Consequently, retailers' focus on enhancing visitors' perception of a pleasant and relaxed ambience will likely result in return visits to the store. In other words, the positive effect of ambience on intention through pleasure outweighs the negative effect through arousal. Given that ambience also affects arousal and arousal decreases the revisit intention, strengthening the feelings of arousal diminishes an individual's revisit intention. Hence, retailers might employ an alternative strategy, that is, dedicate more effort to their employees and how they interact with customers. Employees represent the second strongest indirect determinant of the revisit intention, only having a significant effect on pleasure, but not on arousal. It is worth pointing out that the employees' style of dressing, their reliability, trustworthiness and politeness are the key characteristics that translate into pleasurable experiences of visitors. Interestingly, perceiving visitors as lively, cheerful, and stimulating tends to increase customers' arousal, which, in turn, decreases their intention to return to the store. However, the net effect of the perception of visitors on the revisit intention is negligible.

Additionally, broadening the knowledge base about the customer experience has been provided by demonstrating the moderating role of price consciousness. Consumers differ in their susceptibility to price as a decision-making el- ement in a store. Hence, retailers could infer price-consciousness levels from current and prospective customers by closely examining their responses to prices on retail offerings. If, for example, it turns out that price consciousness among customers is high, this would mean that most customers derive strong feelings of pleasure and arousal from the ambience in question (and to some extent from the social factor). Since pleasure and arousal work in opposite directions when influencing revisit intentions, retailers should ponder whether less-price-conscious consumers are prioritized and put this into perspective when setting their long-term goals.

This study also has several limitations. The data used to test the conceptual model were cross-sectional, while a longitudinal approach could provide more insight into the dynamic and causal nature of the relationships examined. Along these lines, McColl-Kennedy and others (2015) underline the potential of longitudinal research design to identify what influences variability of the customer experience over time. In addition, more specific elements of the environment could be integrated into the model to better explain the customer purchase experience. One limitation also arises from consumers' difficulties in verbalizing and precisely recalling their emotional states. To some extent, the current study has diminished these hurdles by collecting data from customers immediately after they had completed their purchases or their store visits. Furthermore, the focus of this study is the offline retail environment, while nowadays, consumers often combine offline and online shopping. Hence, future research could be directed toward exploring multi-device, multi-channel interactions and experiences (Bilgihan, Kandampully \& Zhang, 2016). Finally, other moderating variables, such as motivational orientation (Kaltcheva \& Weitz, 2006), should be incorporated in future studies. Despite these limitations, the study contributes to the existing knowledge base on the customer experience. 


\section{References}

1. Ailawadi, K. L., Neslin, S. A., \& Gedenk, K. (2001). Pursuing the value-conscious consumer: store brands versus national brand promotions. Journal of Marketing, 65(1), 71-89.

2. Alford, B. L., \& Biswas, A. (2002). The effects of discount level, price consciousness and sale proneness on consumers' price perception and behavioral intention. Journal of Business Research, 55(9), 775-783.

3. Anderson, J. C., \& Gerbing, D. W. (1988). Structural equation modeling in practice: A review and recommended two-step approach. Psychological bulletin, 103(3), 411-423.

4. Baker, J. (1986). The role of environment in marketing services: The consumer perspective. In: J. A. Czpeil, C. Congram \& J. Shanaham (eds.), The services marketing challenge: Integrated for competitive advantage (pp. 79-84). Chicago, IL: American Marketing Association.

5. Baker, J., Grewal, D., \& Parasuraman, A. (1994). The influence of store environment on quality inferences and store image. Journal of the Academy of Marketing Science, 22(4), 328-339.

6. Berry, L. L., Carbone, L. P., \& Haeckel, S. H. (2002). Managing the total customer experience. MIT Sloan Management Review, 43(3), 85-89.

7. Bilgihan, A., Kandampully, J., \& Zhang, T. (2016). Towards a unified customer experience in online shopping environments: Antecedents and outcomes. International Journal of Quality and Service Sciences, 8(1), 102-119.

8. Bitner, M. J. (1992). Servicescapes: The impact of physical surroundings on customers and employees. Journal of Marketing, 56, 57-71.

9. Bolton, R., Gustafsson, A., McColl-Kennedy, J., Sirianni, N., \& K. Tse, D. (2014). Small details that make big differences: a radical approach to consumption experience as a firm's differentiating strategy. Journal of Service Management, 25(2), 253-274.

10. Chahal, H., \& Dutta, K. (2014). Conceptualising customer experiences: Significant research propositions. Marketing Review, 14(4), 361-381.

11. Choudhury, M., Singh, R., \& Saikia, H. (2016). Measuring customer experience in bancassurance: an empirical study. Market-Trziste, 28(1), 47-62.

12. Cronin Jr., J. J., \& Taylor, S. A. (1992). Measuring service quality: a reexamination and extension. Journal of Marketing, 56(3), 55-68.

13. Dabholkar, P. A., \& Bagozzi, R. P. (2002). An attitudinal model of technology-based self-service: moderating effects of consumer traits and situational factors. Journal of the Academy of Marketing Science, 30(3), 184-201.

14. Dasu, S., \& Chase, R. (2013). The Customer Service Solution: Managing Emotions, Trust, and Control to Win Your Customer's Business. Boston, MA: McGraw Hill Professional.

15. Donovan, R., \& Rossiter, J. (1982). Store atmosphere: an environmental psychology approach. Journal of Retailing, 58(1), 34-57.

16. Donovan, R. J., Rossiter, J. R., Marcollin, G., \& Nesdale, A. (1994). Store Atmosphere and Purchasing Behaviour. Journal of Retailing, 70(3), 283-294.

17. Eroglu, S. A., Machleit, K. A., \& Davis, L. M. (2001). Atmospheric qualities of online retailing: A conceptual model and implications. Journal of Business Research, 54(2), 177-184.

18. Farrell, A. M. (2010). Insufficient discriminant validity: A comment on Bove, Pervan, Beatty, and Shiu (2009). Journal of Business Research, 63(3), 324-327.

19. Fornell, C., \& Larcker, D. F. (1981). Evaluating structural equation models with unobservable variables and measurement error. Journal of Marketing Research, 18(1), 39-50.

20. Grewal, D., Levy, M., \& Kumar, V. (2009). Customer experience management in retailing: an organizing framework. Journal of Retailing, 85(1), 1-14. 
21. Hampson, D. P., \& McGoldrick, P. J. (2017). Antecedents of consumer price consciousness in a turbulent economy. International Journal of Consumer Studies, 41(4), 404-414.

22. Hart, C., Farrell, A. M., Stachow, G., Reed, G., \& Cadogan, J. W. (2007). Enjoyment of the shopping experience: Impact on customers' repatronage intentions and gender influence. The Service Industries Journal, 27(5), 583-604.

23. Hoffman, K. D., \& Turley, L. W. (2002). Atmospherics, service encounters and consumer decision making: An integrattve perspective. Journal of Marketing Theory and Practice, 10(3), 33-47.

24. Hudson, J. T., Behe, B. K., Ponder, H. G., \& Barrick, W. E. (1997). Consumer perceptions and expectations of garden center product and service quality. Journal of Environmental Horticulture, 15, 12-15.

25. Jang, S. S., \& Namkung, Y. (2009). Perceived quality, emotions, and behavioral intentions: Application of an extended Mehrabian-Russell model to restaurants. Journal of Business Research, 62(4), 451-460.

26. Johnson, K. K., Kim, H. Y., Mun, J. M., \& Lee, J. Y. (2015). Keeping customers shopping in stores: interrelationships among store attributes, shopping enjoyment, and place attachment. International Review of Retail, Distribution and Consumer Research, 25(1), 20-34.

27. Kaltcheva, V. D., \& Weitz, B. A. (2006). When should a retailer create an exciting store environment?. Journal of Marketing, 70(1), 107-118.

28. Kline, R. B. (2011). Principles and Practice of Structural Equation Modeling. New York, NY: Guilford Press.

29. Koschate-Fischer, N., Hoyer, W. D., Stokburger-Sauer, N. E., \& Engling, J. (2017). Do life events always lead to change in purchase? The mediating role of change in consumer innovativeness, the variety seeking tendency, and price consciousness. Journal of the Academy of Marketing Science, 46(3), 516-536.

30. Lemon, K. N., \& Verhoef, P. C. (2016). Understanding Customer Experience throughout the Customer Journey. Journal of Marketing, 80, 69-96.

31. Lichtenstein, D. R., Bloch, P. H., \& Black, W. C. (1988). Correlates of price acceptability. Journal of Consumer Research, 15(2), 243-252.

32. Lichtenstein, D. R., Ridgway, N. M., \& Netemeyer, R. G. (1993). Price perceptions and consumer shopping behavior: a field study. Journal of Marketing Research, 30, 234-245.

33. Lusch, R. F., Vargo, S. L., \& O'Brien, M. (2007). Competing through service: Insights from service-dominant logic. Journal of Retailing, 83(1), 5-18.

34. Martin, J., Mortimer, G., \& Andrews, L. (2015). Re-examining online customer experience to include purchase frequency and perceived risk. Journal of Retailing and Consumer Services, 25, $81-$ 95.

35. Mattila, A. S., \& Enz, C. A. (2002). The role of emotions in service encounters. Journal of Service Research, 4(4), 268-277.

36. McColl-Kennedy, J. R., Gustafsson, A., Jaakkola, E., Klaus, P., Radnor, Z. J., Perks, H., \& Friman, M. (2015). Fresh perspectives on customer experience. Journal of Services Marketing, 29(6/7), $430-$ 435.

37. Mehrabian, A., \& Russell, J. A. (1974). An Approach to Environmental Psychology. Cambridge, MA: The MIT Press.

38. Meyer, C., \& Schwager, A. (2007). Understanding customer experience. Harvard Business Review, 85, 117-126.

39. Milliman, R. E. (1982). Using Background Music to Affect the Behavior of Supermarket Shoppers. Journal of Marketing, 46(3), 86-91.

40. Moreira, A. C., Fortes, N., \& Santiago, R. (2017). Influence of sensory stimuli on brand experience, brand equity and purchase intention. Journal of Business Economics and Management, 18(1), 68-83. 
41. Morrison, M., Gan, S., Dubelaar, C., \& Oppewal, H. (2011). In-store music and aroma influences on shopper behavior and satisfaction. Journal of Business Research, 64(6), 558-564.

42. Nadiri, H., \& Gunay, G. N. (2013). An empirical study to diagnose the outcomes of customers' experiences in trendy coffee shops. Journal of Business Economics and Management, 14(1), 22-53.

43. Nunnally, J. C., \& Bernstein, I. H. (1994). Psychometric theory. New York, NY: McGraw-Hill.

44. Otterbring, T. (2017). Smile for a while: the effect of employee-displayed smiling on customer affect and satisfaction. Journal of Service Management, 28(2), 284-304.

45. Petermans, A., Janssens, W., \& Van Cleempoel, K. (2013). A holistic framework for conceptualizing customer experiences in retail environments. International Journal of Design, 7(2), 1-18.

46. Pine, B. J., \& Gilmore, J. H. (1998). Welcome to the experience economy. Harvard Business Review, 76, 97-105.

47. Pine, B. J., \& Gilmore, J. H. (1999). The experience economy: work is theatre \& every business a stage. Cambridge, MA: Harvard Business Press.

48. Puccinelli, N. M., Goodstein, R. C., Grewal, D., Price, R., Raghubir, P., \& Stewart, D. (2009). Customer experience management in retailing: understanding the buying process. Journal of Retailing, 85(1), 15-30.

49. Ryu, K., \& Jang, S. (2007). The effect of environmental perceptions on behavioral intentions through emotions: The case of upscale restaurants. Journal of Hospitality \& Tourism Research, 31(1), 56-72.

50. Schmitt, B. (1999). Experiential marketing. Journal of Marketing Management, 15(1/3), 53-67.

51. Schmitt, B. H. (2003). Customer experience management: A revolutionary approach to connecting with your customers. Hoboken, NJ: John Wiley \& Sons.

52. Schmitt, B., Brakus, J. J., \& Zarantonello, L. (2015). From experiential psychology to consumer experience. Journal of Consumer Psychology, 25(1), 166-171.

53. Sherman, E., Mathur, A., \& Smith, R. B. (1997). Store environment and consumer purchase behavior: mediating role of consumer emotions. Psychology and Marketing, 14(4), 361-378.

54. Spence, C., Puccinelli, N. M., Grewal, D., \& Roggeveen, A. L. (2014). Store atmospherics: A multisensory perspective. Psychology \& Marketing, 31(7), 472-488.

55. Spies, K., Hesse, F., \& Loesch, K. (1997). Store atmosphere, mood and purchasing behavior. International Journal of Research in Marketing, 14(1), 1-17.

56. Steenkamp, J. B. E., \& Maydeu-Olivares, A. (2015). Stability and change in consumer traits: evidence from a 12-year longitudinal study, 2002-2013. Journal of Marketing Research, 52(3), 287-308.

57. Vargo, S. L., \& Lusch, R. F. (2004). Evolving to a new dominant logic for marketing. Journal of Marketing, 68(1), 1-17.

58. Verhoef, P. C., Lemon, K. N., Parasuraman, A., Roggeveen, A., Tsiros, M., \& Schlesinger, L. A. (2009). Customer experience creation: Determinants, dynamics and management strategies. Journal of Retailing, 85(1), 31-41.

59. Vieira, V. A. (2013). Stimuli-organism-response framework: A meta-analytic review in the store environment. Journal of Business Research, 66(9), 1420-1426.

60. Wells, W., \& Tigert, D. (1971). Activities, Interests, and Opinions. Journal of Advertising Research, $11(4), 27-35$.

61. Yoon, S., \& Oh, J. C. (2016). A cross-national validation of a new retail customer equity model. International Journal of Consumer Studies, 40(6), 652-664.

62. Zeithaml, V. A., Bitner, M. J., \& Gremler, D. (2009). Services Marketing: Integrating Customer Focus across the Firm. $5^{\text {th }}$ ed. New York, NY: McGraw-Hill/Irwin.

63. Zielke, S., \& Komor, M. (2015). Cross-national differences in price-role orientation and their impact on retail markets. Journal of the Academy of Marketing Science, 43(2), 159-180. 


\section{Appendix}

\begin{tabular}{|c|c|}
\hline Construct & Item \\
\hline \multirow{3}{*}{ Ambience } & The ambience of this garden center is: unpleasant - pleasant. \\
\hline & The ambience of this garden center is: tense - relaxed. \\
\hline & The overall image of this garden center is: bad - good. \\
\hline \multirow{3}{*}{ Social factor } & The visitors of this garden center are: unlively - lively. \\
\hline & The visitors of this garden center are: depressing - cheerful. \\
\hline & The visitors of this garden center are: boring - stimulating. \\
\hline \multirow{4}{*}{ Employees } & The employees of this garden center are well dressed and appear neat. \\
\hline & The employees of this garden center are reliable. \\
\hline & You can trust the employees of this garden center. \\
\hline & The employees of this garden center are polite. \\
\hline \multirow{4}{*}{ Pleasure } & During shopping I felt: annoyed - pleased. \\
\hline & During shopping I felt: unsatisfied - satisfied. \\
\hline & During shopping I felt: despairing - hopeful. \\
\hline & During shopping I felt: bored - relaxed. \\
\hline \multirow{4}{*}{ Arousal } & During shopping I felt: relaxed - stimulated. \\
\hline & During shopping I felt: dull - jittery. \\
\hline & During shopping I felt: sleepy - wide awake. \\
\hline & During shopping I felt: unaroused - aroused. \\
\hline Intention & I will definitely return to the Kalia garden center. \\
\hline \multirow{3}{*}{ Price consciousness } & When shopping, I pay attention to special offers. \\
\hline & When shopping, I examine the prices even for small items. \\
\hline & I usually watch the advertisements for announcement of sales. \\
\hline
\end{tabular}

